\title{
O que sobrevive dos protestos de 2013 em imagens:
}

\author{
re-montando fotografias políticas para ativar um levante \\ democrático
}

\section{What survives from the $\mathbf{2 0 1 3}$ protests in images:}

reassembling political photographs to activate a democratic uprising

Jane Maciel

Professora do Departamento de Comunicação Social da Universidade Federal do Maranhão e Doutora em Comunicação e Cultura pela Escola de Comunicação da Universidade Federal do Rio de Janeiro - ECO/UFRJ Universidade Federal do Maranhão, Departamento de Comunicação Social, São Luís (MA), Brasil.

\section{Introdução}

"É claro que eventualmente levantes podem acontecer e serem rapidamente apagados pela história. Com isso, a teia de citações chega ao fim, e a tarefa política consiste na luta contra o esquecimento". (Judith Butler)

Ao estudarmos as imagens nas redes digitais pelo enfoque da política brasileira, deparamo-nos com certa frequência com a sobrevivência de memórias visuais dos protestos de 2013 conhecidos como jornadas de junho (MARICATO et al, 2013), articuladas a textos que buscam observar continuidades e descontinuidades com as manifestações e acontecimentos políticos que vieram nos anos seguintes. Embora esses reaparecimentos aconteçam, é possível também perceber um esquecimento que suscita, por outro lado, a urgência de recuperação e ativação desse imaginário. Não somente o tempo que passa nos faz esquecer, restando apenas reminiscências fugidias. Nosso esquecimento é também resultado da força da enxurrada de imagens que se movem diante de nossos olhos, que parecem arrastar memórias deixando as marcas das tensões sociais, ou sobrepõem a tensão de cada dia para expor a novidade da revolta 


\section{ALCEU}

política que nunca cessa de ressurgir em novas crônicas. É o esquecimento do amontoado de uma pilha infinita, da despensa, em uma cultura visual cuja marca é a disputa pela atenção no agora, no nível de observação direta do fluxo contínuo e dispersivo.

Neste artigo buscamos debater como a memória visual de 2013, cujo ciclo de protestos se expandiu até 2014, invoca determinadas narrativas políticas e como estas podem ser ativadas por meio de um exercício exploratório de busca, inventário e montagem de imagens fotográficas, bem como pela descrição e problematização de suas agências no texto aqui apresentado. Para tanto, apoiamo-nos em duas perspectivas conceituais/metodológicas como instrumentos de orientação e navegação nesta trama de imagens: uma inspirada pelo Atlas de Imagens Mnemosyne, de Aby Warburg (WARBURG, 2010; DIDIHUBERMAN, 2013a, 2013b), e a outra guiada pela Teoria Ator-Rede, a partir da obra de Bruno Latour (2007). Estas duas formas cartográficas auxiliaram-nos a propor um dispositivo de relação entre-imagens e de investigação de seus rastros digitais, com ênfase em suas dinâmicas comunicacionais.

Acreditamos que fotografias são ativadas em rede, onde o debate da comunidade lança olhares sobre os processos de construção de seus códigos, as designações e os usos possíveis, os rastros de origens, as apropriações e os desvios simbólicos, bem como o cruzamento com outras imagens que indicam como seus sentidos e suas agências são continuamente transformados. Este artigo reúne um conjunto de fotografias em uma superfície, uma prancha inspirada naquelas construídas por Warburg em seu Atlas de Imagens, que será apresentada junto a um relato sobre seus usos em rede, composto dos vínculos pelos quais é possível re-construir memórias desses protestos. As imagens são problematizadas não de maneira isolada, mas no trabalho de relação das formas, sentidos, afetos e ações por elas movimentadas. Este texto não busca construir uma explicação estanque sobre 2013, mas apresentar uma narrativa pela qual é possível reativar as imagens dispostas em nossa mesa de trabalho (DIDI-HUBERMAN, 2013b), que são simultaneamente mapas de memória e legibilidade daquilo que surgiu na esfera midiática como imagem e imaginário político.

Deste modo, partimos de uma seleção de fotografias de 2013 e 2014 reunidas no projeto Atlas \#ProtestosBR, cujo arquivo foi montado pelo envio de pessoas anônimas por meio de uma chamada pública lançada logo em 2013, mas que já manifestava a preocupação com a reminiscência assumindo uma 
tarefa de mediação tecnopolítica. ${ }^{1}$ Levando em consideração sua extensão e diversidade, optamos por eleger em sua maioria fotografias icônicas, que foram compartilhadas amplamente em diferentes ambientes midiáticos, mas também outras menos conhecidas, devido ao potencial de criar um efeito dialético no corpus estudado, ou, ainda, por ilustrarem aspectos relevantes em relação aos objetivos teóricos deste artigo: levantar questões sobre o que seriam imagens/fotografias políticas e tecnopolíticas neste contexto brasileiro, a partir de um recorte temático que nos permitirá guiar tanto a montagem visual como a escritura do texto, o conceito de democracia.

Dentre o abrangente arcabouço teórico que discute essa noção, optamos trabalhar com a base conceitual proposta pela filosofia política de Jacques Rancière (1996, 2009, 2012, 2014), que a aproxima do conceito de estética e propõe uma perspectiva que se alinha com o estudo das imagens como atores que participam na ação coletiva, e não apenas sendo signos que as representam. Nesta, a estética está na base da política, pois remete às visibilidades dos assuntos da comunidade e dos conflitos das partes sociais. Segundo Rancière (1996), a fala assume no contexto democrático uma acepção fundadora na constituição do mundo político, em um logos estabelecido na aisthesis. A constituição da subjetivação política coincide com a construção dessa fala em uma cena comum igualmente elaborada, tendo por essência democrática a igualdade e a liberdade de qualquer um, mesmo os "não contados", que, no entanto, devem assumir constantemente a postura de enfrentamento para manifestar o "dano" das más distribuições. É nesta cena que a fala se apresenta como manifestação estética de modos de subjetivação e seus respectivos campos de experiências.

No que se refere ao próprio nó do logos e de sua consideração com a aisthesis - a divisão do sensível -, sua lógica da demonstração é indissoluvelmente uma estética da manifestação. A política não sofreu, recentemente, a desgraça de ser estetizada ou espetacularizada. A configuração estética na qual se inscreve a palavra do ser falante sempre constituiu o próprio cerne do litígio que a política vem inscrever na ordem policial. [...] A "estética" é, ao contrário, o que coloca em comunicação regimes separados de expressão. (RANCIÈRE, 1996, p.68, grifos do autor)

As imagens são simultaneamente elementos fundamentais de nossos processos de subjetivação (entre eles, as subjetivações políticas) e mediadoras (LATOUR, 2007) que deslocam ações coletivas, ao permitirem que se reivindiquem singularidades e se negocie a todo momento a experiência de coabitação no comum. Elas constituem uma "fala" que se organiza de modo distinto daquele tradicionalmente

\footnotetext{
${ }^{1}$ A partir da pergunta "quais imagens dos protestos sobrevivem em sua memória?", usuários anônimos fizeram uploads de imagens na plataforma. Centenas de registros, em grande parte fotografias, foram reunidos no site http://medialabufrj.net/mnemopolis/atlas/.
} 
atribuído ao logos retórico. No que tange à fotografia, meio que serve ao aparecimento de fragmentos de fatos em diferentes perspectivas, enquadramentos, instantes e montagens, é notória a participação desta linguagem e tecnologia visual na construção do fazer coletivo dos levantes (DIDI-HUBERMAN, 2017). Em nossa atualidade política, fotografias não somente registram, mas são parte constituinte das estratégias de construção e propagação de imaginários que, em rede, irão chocar-se e disputar narrativas sobre o que se anseia para a sociedade, quais direitos se buscam e quais subjetividades políticas os reivindicam (ou não), quais lutas emergem junto a modos de existência. Como as imagens/fotografias oferecem uma via para ativar acontecimentos políticos recentes, porém já tão esquecidos no fluxo das visualidades contemporâneas? E, mais ainda, como podemos contribuir no campo da comunicação social para o entendimento sobre como as imagens agem, como fazem surgir outros atores políticos (e não somente como representam ou informam)? Essas são perguntas complexas que este trabalho deseja apontar nos caminhos pela experimentação criativa do saber impuro - inteligível e sensível - das imagens (DIDIHUBERMAN, 2013b).

\section{3-2014: imagens em levante}

Retornar às fotografias dos protestos que alcançaram abrangência nacional em 2013 a partir da reivindicação da redução das tarifas de transporte público, mas que tiveram uma expansão temporal até $2014,{ }^{2}$ é uma tarefa assumida neste artigo pelo viés do potencial político de ativação mnemônica de imagens que, conforme explicamos, foram reunidas de modo anônimo e distribuído. Das infinitas combinações que poderíamos compor, selecionamos algumas fotos que consideramos potentes para discutirmos o que seria política, tecnopolítica e as nuances da noção de democracia perceptíveis nessas manifestações, e que achamos ser capazes de mostrar certa diversidade dos protestos e das agências das imagens nas redes sociotécnicas (LATOUR, 2007). A partir desta seleção, voltamos às redes digitais para pesquisar rastros dessas memórias por meio da ferramenta de busca por imagens, no Google, além de páginas em redes sociais, sites de notícias, blogs, entre outros. A prancha que aqui apresentamos paralisa em um plano essa constelação visual formada por imagens que expressam dinâmicas próprias daqueles

\footnotetext{
${ }^{2}$ Consideramos neste trabalho que os protestos de 2013 não terminaram naquele ano, o que é perceptível tanto pela análise do corpus reunido no arquivo do Atlas \#ProtestosBR, em que constam imagens de 2013 e 2014 (além de outras digressões temporais e mesmo espaciais), mas também nos rastros que essas imagens deixam nas redes digitais, em que é possível perceber uma forte vinculação das pautas, estéticas, táticas, posicionamentos ideológicos e outras configurações coletivas das manifestações nesses dois anos. Contudo, é necessário remarcar que nossa intenção não é apresentar historicamente tais movimentos, mas sim debatê-los pelo viés da comunicação. Há muitas publicações que se voltaram para esses protestos. Citemos como exemplo uma coletânea lançada a cabo dos acontecimentos, Cidades Rebeldes (MARICATO et al, 2013).
} 


\section{ALCEU}

levantes, mas que certamente se conectam a muitos outros, seja pela semelhança ou pela diferença. No relato que a acompanha consta tanto a descrição das fotos e de suas características de produção e circulação quanto o debate teórico que estas instigam pelos vínculos entre-imagens, que possibilitam dinamizar suas tensões. Nossa aposta metodológica é que esse dispositivo visual e textual seja capaz de propor uma análise política da imagem fotográfica em rede.

Imagem 1: Prancha Levantes 2013-2014

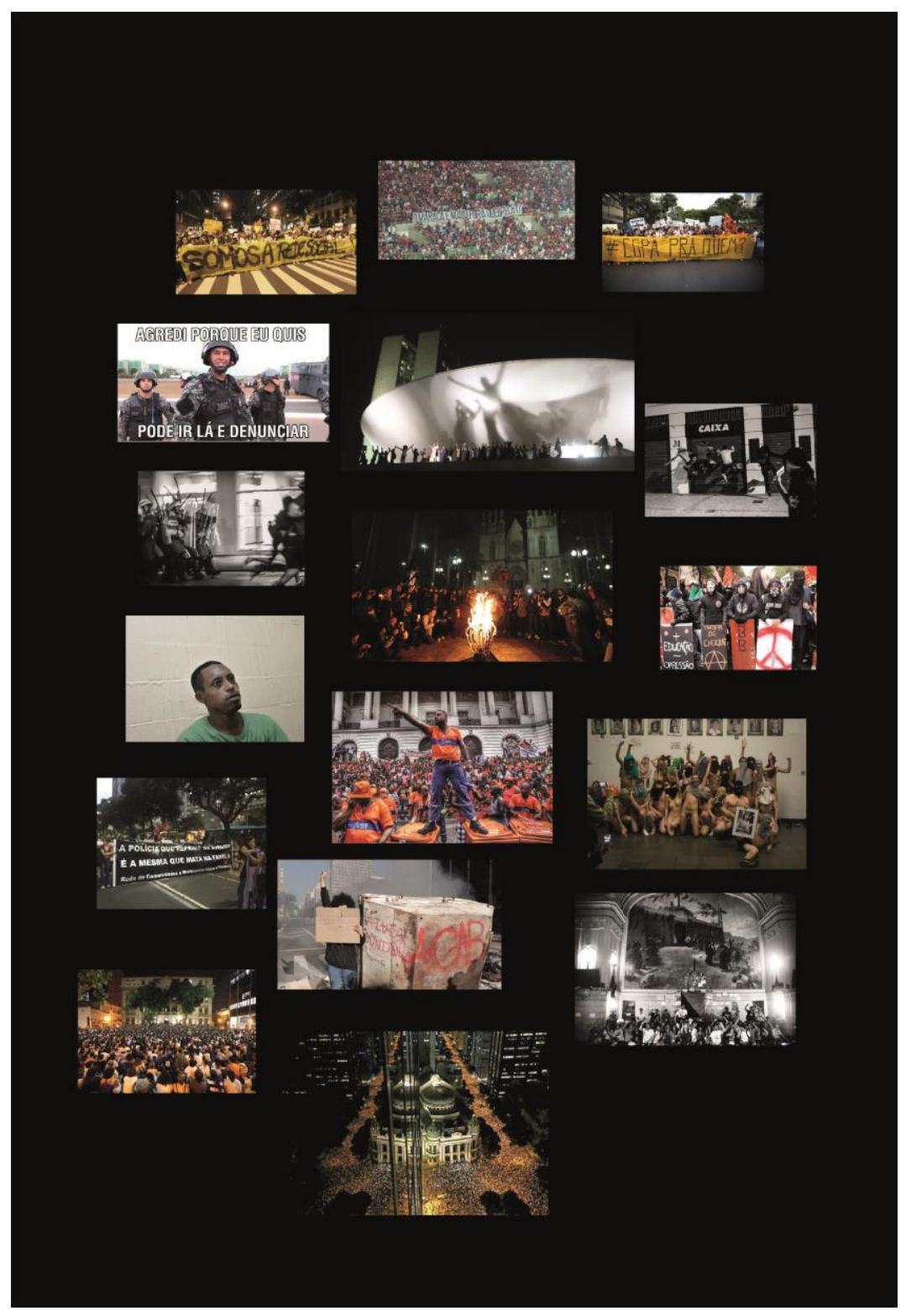

Autoria nossa 
Comecemos pelas fotos de catracas queimadas, tão recorrentes no arquivo. A fotografia de divulgada no site do Movimento Passe Livre - São Paulo (MPL-SP), ${ }^{3}$ ator-rede (LATOUR, 2007) fundamental para o surgimento das Jornadas de Junho, traz toda a potência da performatividade dos atos e das imagens. Uma catraca de ônibus está no centro da foto noturna tirada em frente à Praça da Sé de São Paulo. Ao seu redor, manifestantes, fotógrafos e cinegrafistas - muitos deles fundindo-se como "mídiamultidão" (BENTES, 2015) - observam e registram as labaredas no símbolo do transporte público tratado como mercadoria, controlador das dinâmicas de ir e vir e, portanto, do direito à cidade, que o movimento reivindica como mote central: “As catracas de transporte são uma barreira física que discrimina, segundo o critério de concentração de renda, aqueles que podem circular pela cidade daqueles condenados à exclusão urbana." (Movimento Passe Livre - São Paulo in MARICATO, p.15, 2013). A foto de 14 de agosto de 2013, meses depois dos primeiros atos de São Paulo, que se difundiram pelo Brasil e conquistaram a revogação do aumento das tarifas de transporte público em mais de cem cidades, mostra-se como um registro hipermidiatizado, já que as câmeras parecem disputar o protagonismo do ritual da catraca flamejante. Este serve para chamar atenção tanto para quem passa no local estrategicamente escolhido, como para quem teria acesso ao registro nas redes que naquele momento ainda pulsavam fortemente o imaginário das jornadas.

$\mathrm{Na}$ foto, tudo parece elaborado para se converter em imagem: a igreja ao fundo é um marcador espacial, a noite faz as chamas parecerem mais expressivas, os rostos iluminados da primeira fila não só observam, registram. A catraca de metal está envolta de papel que queimará por breves instantes, assim como fizeram em outros atos, que, ao circularem por São Paulo, foram duramente reprimidos. As ruas tiveram sua dinâmica cotidiana substituída por outra, e a cada vez que a tentativa de restituição dessa distribuição anterior foi realizada por meio da violência contra manifestantes, outros atos foram convocados valendo-se constantemente das redes sociais como ferramentas e das imagens como conteúdos das incitações à continuidade das lutas. Neste sentido, é preciso remarcar que o próprio MPL não teve relevância midiática logo de início; o que chamamos de "protestos de junho de 2013" só aconteceu por uma série de fatores que em muito escapou do próprio fazer direto do movimento/coletivo

\footnotetext{
3 A manifestação aconteceu contra o suposto cartel do metrô, segundo o site do MPL-SP. Disponível em: https://saopaulo.mpl.org.br/14ago2013-manifestantes-colocam-fogo-em-catraca-na-praca-da-se-no-centro-de-sao-paulodurante-manifestacao-contra-o-suposto-cartel-do-metro-1376525907475_1920x1080/
} 
e que passou por diversas dinâmicas imagéticas/midiáticas que até hoje mobilizam reflexões no campo da comunicação e da política.

De maneira inicial, os próprios manifestantes mostraram com suas imagens amadoras o comportamento violento da polícia nos primeiros atos na cidade de São Paulo. Posteriormente, estas denúncias transbordaram as redes sociais e foram pautadas também pela mídia corporativa, especialmente quando seu pessoal passou a ser atingido com truculência, ${ }^{4}$ o que mobilizou certa comoção na cobertura e, por conseguinte, ampliação da escala dos protestos. ${ }^{5}$ Inspirados nas lutas de outros países, vimos atualizar nossas próprias perspectivas do que seria a tecnopolítica, "uso tático e estratégico de dispositivos tecnológicos (incluindo as redes sociais) para a organização, comunicação e ação coletiva" (TORET, 2013, p.2). ${ }^{6}$ Foi nesse contexto comunicacional, por exemplo, que o coletivo Mídia Ninja construiu sua força como um ator-rede (LATOUR, 2007) capaz de fazer agirem sujeitos e coletivos, ao passo que criava um extenso banco de imagens digitais em suas plataformas, ${ }^{7}$ pelas quais podemos até hoje ter acesso a pontos de vista advindos de dentro dos protestos, muitos deles afetados pelo clima de tensão do seu interior; enquanto manifestantes corriam das bombas de gás lacrimogênio e de efeito moral, balas de borracha e tropas de choque, capturavam em fotografias e vídeos - muitas vezes de modo trêmulo, fugidio e em tempo real - rastros visuais dos "\#ProtestosBR". Assim foi possível configurar toda uma visualidade que contrastava com a dos veículos midiáticos corporativos, já que "estes - e esta seria uma das formas de

\footnotetext{
${ }^{4}$ Um exemplo significativo é a imagem da jornalista Giuliana Vallone, da Folha de São Paulo, alvejada no olho com uma bala de borracha. Ver "Reporter tells how the Police brutality marked the latest protest" (12:52), vídeo produzido pela TV Folha e publicado no dia 16 de julho de 2013, disponível em: https://youtu.be/W6QVLE8PQJ8. Sobre os casos de violência contra a imprensa em manifestações, a Associação Brasileira de Jornalismo Investigativo (ABRAJI) contabilizou 102 ocorridos entre junho e outubro de 2013. Ver: https://www.ebc.com.br/noticias/brasil/2013/10/abraji-registra-102-casos-de-agressao-a-jornalistasdurante-cobertura-das

${ }^{5}$ Este ponto é comentado por Lincoln Seco a partir dos números de manifestantes apontados pela Polícia Militar de São Paulo, DataFolha e Brasil de Fato, entre 6 e 22 de junho de 2013 em São Paulo, que menciona a ação policial como fator que promove maior alteração na dinâmica dos protestos, que tiveram seu ápice quantitativo entre os dias 19 e 21: “O ataque a jornalistas e um movimento com a aparente composição social de 'classe média' pode ter facilitado a solidariedade ao movimento. Acompanhando seu mercado, a direita midiática se viu forçada a apoiar os manifestantes - mas com sua própria pauta." (SECO in MARICATO et al, 2013, p.74). Para este autor, "o decisivo não foi a violência, tão natural contra trabalhadores organizados, e sim sua apropriação pela imprensa" (op.cit.). No entanto, consideramos que não apenas a grande mídia foi fundamental para a expansão dos protestos em número de manifestantes e de cidades envolvidas, mas sim toda uma configuração de visibilidades entre as redes digitais e os meios de comunicação de massa, inclusive considerando as disputas e as retroalimentações discursivas entre esses dois universos.

6 Tradução do texto: "como el uso táctico y estratégico de dispositivos tecnológicos (incluyendo redes sociales) para la organización, comunicación y acción colectiva."

${ }^{7}$ Além dos álbuns fotográficos na página do Facebook e do Flickr do coletivo, em que é possível recuperar um amplo arquivo fotográfico das manifestações, uma interessante seleção de imagens é comentada na retrospectiva "Ninja 2013", disponível em: https://medium.com/@MidiaNINJA/ninja-2013-f6d5618375b2
} 


\section{ALCEU}

ISSN: $2175-7402$

distinguir o jornalista profissional do midiativista - lutam menos por uma intervenção ou ação sobre os fatos e mais pela captação e monetização da atenção e do desejo do espectador" (BENTES, 2015, p.27).

Mais as imagens de repressão e violência circulavam, maiores multidões se formavam, e seus registros repercutiam como potência democrática. Fotos de grandes avenidas ocupadas, como a Rio Branco no Rio de Janeiro, em 17 de junho de 2013, são imagens sobreviventes recorrentes no arquivo do Atlas. Esta foi fotografada no alto de um prédio, servindo de prova visual para a abrangência e adesão daquele movimento; ${ }^{8}$ como artifício estético, o fotógrafo optou por compor o enquadramento com o reflexo da vidraça, fazendo dobrar na imagem aquela multidão de corpos anônimos. Em Brasília, no mesmo dia, manifestantes ocuparam o Congresso Nacional. Subiram na rampa de mãos dadas, com braços erguidos, dominaram com suas silhuetas e gigantes sombras a arquitetura imponente. ${ }^{9}$ Circulando em redes sociais, páginas de jornais, na televisão e até assumindo o centro de um cartaz de longa-metragem produzido por uma grande empresa de mídia, ${ }^{10}$ a fotografia dos manifestantes no Congresso fincou-se na memória social e na iconografia da história brasileira. Registradas por múltiplas câmeras, essas fotografias sintetizavam o âmago de uma conquista coletiva, mesmo sendo esta mais simbólica que efetivamente pragmática, uma vez que as revogações dos aumentos ainda estavam sendo naquela altura negociadas, e as demais pautas eram dispersas.

Esses registros triunfantes de ocupações do espaço público carregam implicitamente as tensões das tentativas de silenciamento - e de ocultamento - desses movimentos. Na dispersão das manifestações, os dispositivos de captura e compartilhamento de imagens faziam parte concomitantemente das estratégias de luta, como o copwatch, que consiste no "ato de vigiar os vigilantes com fotografias e transmissões online que expõe e monitora a polícia" (BENTES, 2015, p.51), mas também de vigilância/controle por parte de agentes da polícia, que em alguns casos "fichavam" visualmente manifestantes. Em outros, câmeras fotográficas, celulares e cartões de memória foram apreendidos e/ou danificados, além das muitas pessoas que foram detidas por registrar e/ou transmitir ao vivo a violência das ruas. Todo esse cenário de guerrilha

\footnotetext{
${ }^{8}$ Fotografia de Fabio Motta/Estadão. Disponível em: https://jornalggn.com.br/politica/o-teatro-municipal-carioca-na-noite-deontem/

9 Fotografia de Pedro Ladeira/Folhapress. Disponível em: https://www1.folha.uol.com.br/ilustrada/2018/08/retrato-dasmanifestacoes-populares-de-2013-junho-ajuda-a-entender-o-que-vivemos-hoje-shtml

${ }^{10}$ Referimo-nos ao filme Junho, produção da Folha de São Paulo. Ver: https://m.folha.uol.com.br/ilustrada/2014/06/1462506filme-junho-leva-ao-cinema-os-protestos-de-2013-no-pais.shtml e https://arte.folha.uol.com.br/tvfolha/2014/05/20/junho/
} 
das imagens manifesta energias contidas no lugar de resistência ao assujeitamento que se efetiva na luta pelo direito de expor nas ruas as heterogêneas aspirações políticas que permearam os protestos de 2013.

Como em muitos levantes ao longo da história, o descontentamento pungente diante de determinados padrões societários coincide com a aversão direta às instituições responsáveis pela segurança pública que exercem a coerção do Estado. Suas ações violentas continuaram nos meses que seguiram junho, delineando a pauta contra a militarização das polícias brasileiras. A imagem de um policial militar do Distrito Federal rindo para as câmeras tornou-se meme com a frase "Agredi porque eu quis / Pode ir lá e denunciar". Entre a foto, o vídeo e as diversas versões meméticas, a montagem traz o escancaramento da violência diante de qualquer tentativa disruptiva à ordem estabelecida. Naquele caso específico, manifestantes tentavam chegar ao Congresso Nacional com uma bandeira com mensagens antiCopa; sendo abordados pela polícia, mantiveram-se no limite imposto pelo capitão, e, mesmo assim, acabaram sendo atingidos com gás lacrimogênio. ${ }^{11} \mathrm{~A}$ ação do impasse entre polícia e ativistas foi filmada por estes, que editaram o vídeo em caráter de denúncia. ${ }^{12} \mathrm{~A}$ bandeira com a inscrição "Unfair players Fifa police"13 não chegou ao Congresso; contudo, de algum modo, a ação política dos manifestantes foi exitosa, instaurando um dissenso (RANCIÈRE, 1996) ao fazer ver o "jogo injusto" da ação dos policiais militares, que corresponde à ação policial de gestores públicos que mediaram os interesses privados em torno da Copa do Mundo de 2014.

Segundo Jacques Rancière (1996, p. 41), a definição de política baseia-se no distanciamento daquilo que se compreende usualmente por esse termo, que para ele é entendido de maneira diametralmente inversa como polícia: "[...] o conjunto dos processos pelos quais se operam a agregação e o consentimento das coletividades, a organização dos poderes, a distribuição dos lugares e funções e os sistemas de legitimação dessa distribuição". Conforme esse autor, a "baixa polícia", que se apresenta nas instituições

\footnotetext{
11 Ver: http://g1.globo.com/distrito-federal/noticia/2013/09/porque-eu-quis-diz-pm-questionado-por-jogar-gas-em-jovens-nodf-veja.html

12 Ver: https://youtu.be/7145WvLzubA

${ }^{13}$ Não é possível ver com detalhes o conteúdo da bandeira no vídeo, mas pudemos rastrear por fragmentos que esta fora usada em diversos protestos. Inicialmente como "Unfair players Fifa police Anastasia", em junho de 2013 em Minas Gerais, disponível em https://noticias.r7.com/minas-gerais/fotos/mineiros-abusam-da-criativade-nos-cartazes-levantados-durante-protestos-embh-30062013\#!/foto/4 . Posteriormente a referência ao governador Anastasia foi substituída pelos nomes de outros gestores públicos, Cabral e Paes, em 2013, no Rio de Janeiro, Dilma e Alckmin, no ato em São Paulo em 2014. Disponível em: https://oglobo.globo.com/rio/as-imagens-das-manifestacoes-neste-domingo-8862324 https://anthropoliteia.net/category/commentary-forums/security-in-brazil-world-cup-2014-and-beyond/ https://www.opendemocracy.net/en/opensecurity/copa-pra-quem/.
} 
designadas como "polícia", em suas diferentes unidades constitucionalmente responsáveis pela manutenção da ordem e da lei, é uma das engrenagens da polícia, que, como conceito, exprime a ordem que dispõe o sensível em designações de lugares e tarefas na configuração comum e que, uma vez confrontada, promove o rompimento dessa configuração ao redefinir os lugares e os atores do fazer político.

Ao contrário, a política

[...] rompe a configuração do sensível na qual se definem as parcelas e as partes ou sua ausência a partir de um pressuposto que por definição não tem cabimento ali: a de uma parcela dos sem-parcela. Essa ruptura se manifesta por uma série de atos que reconfiguram o espaço onde as partes, as parcelas e as ausências de parcelas se definiam. A atividade política é a que desloca um corpo do lugar que lhe era designado ou muda a destinação de um lugar; ela faz ver o que não cabe ser visto, faz ouvir um discurso ali onde só tinha barulho, faz ouvir como discurso o que só era ouvido como barulho. (RANCIÈRE, 1996, p. 42)

Para Rancière, a cena política entendida pelo prisma da democracia apresenta-se quando um "dissenso" é instaurado na ordem policial, quando o consenso vigente é desestabilizado pela liberdade e igualdade de qualquer ser falante em relação a outro ser falante, sobretudo quando este deixa claras as assimetrias cotidianas nas distribuições no mundo comum, de maneira que "a sociedade não igualitária só pode funcionar graças à multitude de relações igualitárias. É esse intrincamento de igualdade com desigualdade que o escândalo democrático manifesta para fazer dele o próprio fundamento do poder comum" (RANCIÈRE, 2014, p. 65). Neste âmbito de pensamento, é a própria palavra/ideia de democracia que deve ser questionada, virada ao avesso, pois, tal como ela é usualmente mencionada, refere-se a "[...] um funcionamento estatal e governamental que é o exato contrário [...] apropriação da coisa pública por uma sólida aliança entre a oligarquia estatal e a econômica" (p. 93).

Assim como o caso da faixa acima citada, que está invisível no meme do capitão da PM com seu "porque eu quis", mas que faz parte das imagens-rede que the dão sentido, muitas outras fotografias expressavam a recusa ao evento da Copa do Mundo, cuja aceitação foi defendida como um consenso calcado no estereótipo "Brasil, país do futebol". As pautas antiCopa, e posteriormente contra os megaeventos de maneira mais ampla, incluindo as Olimpíadas em 2016, estiveram no centro do debate das jornadas de junho em estados como Rio de Janeiro, São Paulo, Distrito Federal e Minas Gerais. Em junho e julho de 2013, foi recorrente a reivindicação que dizia que os serviços públicos deveriam seguir os "padrões FIFA". A hashtag \#CopapraQuem não se limitou às redes sociais e esteve presente como grande 
faixa à frente do ato em 17 de junho de 2013 em Belo Horizonte, data da primeira partida da Copa das Confederações no estádio Mineirão, ${ }^{14}$ onde se concentraram manifestantes do movimento Comitê Popular dos Atingidos pela Copa em Belo Horizonte (Copac-BH). ${ }^{15}$ No estádio Maracanã, houve a denúncia à interferência econômica das obras de grandes empreiteiras em detrimento do uso popular dos estádios de futebol. Com o enunciado "O Maracanã é nosso. Fora Odebrecht!", torcedores estenderam uma faixa num jogo em agosto de 2013, que foi recolhida após abordagem da polícia militar; no estádio privatizado, a manifestação política dissensual era proibida, mesmo não havendo nenhuma mensagem ofensiva. ${ }^{16} \mathrm{O}$ que essas fotos têm em comum? São fotos-enunciados, que, junto aos corpos dos manifestantes ou dos torcedores anônimos, assumem seu manifesto conciso que, convertido em pixels, se torna apto para ser compartilhado livremente nos ambientes virtuais.

Em 2013, faixas e cartazes ${ }^{17}$ foram mídias recorrentes para a manifestação do dissenso em diferentes vertentes, mostrando que, desde o início dos protestos, "não era apenas por 20 centavos", como insistia o mote popular que tratava da abrangência política das reivindicações. "Somos a rede social", dizia a faixa à frente do ato de 17 de junho, no Rio de Janeiro. ${ }^{18}$ Enquanto as ruas e as redes ampliavam a diversidade - e a divergência - de pontos de vista políticos, por outro lado, a cobertura da grande mídia noticiava as manifestações em diferentes cidades como a "festa da democracia", 19 ao passo que criava

\footnotetext{
${ }^{14}$ Disponível em: https://www.diarioliberdade.org/brasil/311-resenhas/39713-das-ruas-do-brasil-há-o-canto-da-copa,-eu-abromão,-quero-o-dinheiro-para-saúde,-moradia-e-educação.html

${ }^{15}$ Sobre o movimento e outro rastro desta imagem, ver a dissertação "MOBILIZAÇÃO SOCIAL, ACONTECIMENTOS E OPINIÃO PÚBLICA: O posicionamento estratégico do Comitê Popular dos Atingidos pela Copa em Belo Horizonte (Copac-BH)", de Clara Soares Braga (2015), disponível em: https://repositorio.ufmg.br/bitstream/1843/BUBDAQGJUT/1/dissertacao_clarasoaresbraga.pdf

${ }^{16}$ Foto de Pedro Henrique Torre. O Consórcio Maracanã S.A, que administra o estádio, afirmou em nota que "a retirada da faixa alusiva à reestatização da administração do estádio foi realizada pela Polícia Militar em cumprimento ao Estatuto do Torcedor", que considera que "são condições de acesso e permanência no recinto esportivo, não portar ou ostentar cartazes, bandeiras, símbolos ou outros sinais com mensagens ofensivas [...] utilizar bandeiras, inclusive com mastro de bambu ou similares, para outros fins que não o da manifestação festiva e amigável". Disponível em: http://www.espn.com.br/noticia/352100_protestoscontra-consorcio-dentro-do-maracana-sao-coibidos

${ }_{17} \mathrm{Um}$ arquivo importante de fotografias de cartazes de 2013 foi reunido no projeto colaborativo Grafias de Junho, que faz parte da pesquisa de doutorado em história das cidades de Roberto Andrés. Disponível em: https://www.grafiasdejunho.org/

${ }^{18}$ Disponível em: https://pt.globalvoices.org/2013/06/20/protestos-brasil-internet-denuncia-e-mobilizacao/.

${ }^{19}$ No que tange à cobertura das manifestações pela "velha mídia", Venício A. de Lima considera que: "A primeira reação foi de condenação pura e simples. As manifestações deveriam ser reprimidas com rigor ainda maior. À medida, no entanto, que o fenômeno se alastrou, a velha mídia alterou radicalmente sua avaliação inicial. Passou então a cobrir em tempo real os acontecimentos, como se fosse apenas uma observadora imparcial, que nada tivesse a ver com os fatos que desencadearam todo o processo. 0 que começou com veemente condenação transformou-se, da noite para o dia, não só em tentativa de cooptação, mas também de instigar e pautar as manifestações, introduzindo bandeiras aparentemente alheias à motivação original dos manifestantes." (LIMA in MARICATO ET AL, 2013, p.92)
} 
paulatinamente os discursos do que seria uma "manifestação pacífica" em oposição às imagens de depredação de patrimônio público e privado, resumidas a ações de "vândalos" e "baderneiros", que, "infiltrados" nas manifestações, motivariam e justificariam a ação policial. Colocamos entre aspas por considerarmos que essas expressões e suas dicotomias simbólicas são negociadas por uma série de enunciados (HALL, 2016): entre eles, as imagens que dependem dos olhares que lhes atribuem sentido. Afinal, "qualificar um levante como 'violento 'pode ser um dispositivo retórico para reprimi-lo" (BUTLER in DIDI-HUBERMAN, 2017, p.34).

Citemos a foto que capturou o instante em que uma porta da agência da Caixa Econômica Federal foi atingida por chutes de quatro manifestantes. Na fotografia noturna, em preto e branco, é possível identificar que pelo menos um deles tem o rosto coberto por uma camiseta e que uma mulher faz parte da ação. Ora, não à toa o alvo é a porta de um banco, em uma imagem que faz emergir a aparição do ódio implícito ou explícito - à ideia sustentada como democracia, já que esta palavra funciona constantemente como um "operador ideológico que despolitiza as questões da vida pública para transformá-las em 'fenômenos de sociedade', ao mesmo tempo que nega as formas de dominação que estruturam a sociedade" (RANCIÈRE, p.116-117, 2014).

A fotografia faz parte de uma série disponível no site da fotojornalista Ana Carolina Fernandes, "Brazil - A representação da resistência", 20 na qual é possível ampliar essa reflexão pelo modo como o sentido é construído entre-fotos: caixas de banco são depredados, ônibus são queimados, barricadas são criadas com objetos quebrados e incendiados, enfrentamento direto diante da polícia, gestos agressivos de manifestantes mascarados etc. São fotos que demonstram a resistência às forças públicas e privadas, corpos que criam um atrito com a cidade e seus poderes, e não simplesmente passam por ela. Este atrito (ou a falta dele) não está apenas nos atos, mas nas fotografias que, em si, são imagens-ato (DUBOIS, 1993). O "Brazil" grafado como uma palavra estrangeira conecta aquele ciclo de lutas a tantos outros "movimentos altermundialistas e as primaveras da indignação", que, conforme afirma Antonio Negri (in DIDI-HUBERMAN, p.43), são lutas que "representam o paradigma de um movimento que cresce, continua e se aprofunda, mesmo que por meio de derrotas".

\footnotetext{
${ }^{20}$ Disponível em: http://anacarolinafernandes.com.br/brazil-the-representation-of-the-resistance/
} 
Jacques Rancière (1996, p. 51) afirma que a sociedade democrática acontece quando os sujeitos são capazes de apropriar-se de palavras, imagens e formas de vivência, e articulam situações que fazem ver o dano que institui "[...] um universal polêmico, vinculando a apresentação da igualdade, como parte dos sem-parte". Este "deve pressupor essa igualdade dos seres falantes que contradiz a distribuição policial dos corpos colocados em seu lugar e estabelecidos em sua função." (p. 46). Para além das posturas reativas, inúmeras ações propositivas permearam as jornadas, que se expandiram por meses que mostraram um forte anseio pela redefinição e reconstrução da experiência em democracia. A fotografia do Largo de São Francisco, no Centro do Rio, ocupada pela plenária que discutiu as pautas das lutas de junho de $2013,{ }^{21}$ os registros da ocupação por manifestantes das câmaras de vereadores do Rio de Janeiro e de Porto Alegre, sendo esta última marcada pela foto de manifestantes nus e com rostos cobertos diante da galeria de fotos dos vereadores, ${ }^{22}$ o gesto altivo do gari à frente da multidão de grevistas que paralisaram a limpeza urbana do Rio de Janeiro em pleno carnaval de $2014^{23}$ são imagens marcantes não somente pelos acontecimentos que representam, mas porque, em cada uma, há uma constituição estética/metafórica que desloca o que podemos pensar e sentir sobre a possibilidade de vivenciar aquilo que denominamos como política.

O primeiro pedido de universalidade é o da presença universal dos seres falantes à comunidade da linguagem. E ele sempre é tratado em situações "anormais" de comunicação, em situações que instauram casos". Essas situações polêmicas são aquelas em que um dos parceiros da interlocução se recusa a reconhecer um de seus elementos (seu lugar, seu objeto, seus sujeitos...).[...] É preciso antes de tudo reconhecer e fazer reconhecer que uma situação apresenta um caso de universalidade que obriga. E esse reconhecimento não autoriza a separar uma ordem racional da argumentação de uma ordem poética, senão irracional, do comentário e da metáfora. Ele é produzido por atos de linguagem que são, a um só tempo, argumentos racionais e metáforas "poéticas". (RANCIÈRE, 1996, p.67)

Vejamos a fotografia na câmara municipal de Porto Alegre. A redistribuição dos corpos assume uma jogada simbólica no registro, que faz ver a recorrente estratégia das ocupações: neste caso, da sede do poder legislativo, com corpos e performances completamente avessas àquele lugar e às suas funções.

\footnotetext{
21 Fotografia disponível em: https://oglobo.globo.com/rio/datas-das-proximas-manifestacoes-no-rio-sao-definidas-aposplenaria-8819018 e em https://forajidosdelanetwar.wordpress.com/2013/07/01/los-indignados-de-brasil-la-revuelta-de-losveinte-centavos/

Sobre a plenária, ver: https://ufrj.br/noticia/2015/10/22/plen-ria-no-ifcs-recebe-3-mil-pessoas-em-debate-sobre-transportes

22 Fotografia disponível em: http://g1.globo.com/rs/rio-grande-do-sul/noticia/2013/07/fotos-mostram-manifestantes-semroupa-na-camara-de-porto-alegre.html. Uma rica análise sobre esta fotografia pode ser acessada na tese de doutorado de Carolina Libério, "Eu que não quero ter rosto", disponível em: http://www.pos.eco.ufrj.br/site/download.php?arquivo=upload/tese_cliberio_2018.pdf

${ }^{23}$ Fotografia da Mídia Ninja, disponível em: https://www.flickr.com/photos/midianinja/14715885334
} 
Nela, os quadros dos vereadores estão invertidos na parede. A fotografia, portanto, faz ver a inversão a que aquela ação se propõe: em vez da política exposta em rostos nas paredes da formal galeria - dos velhos homens brancos (de cabeça para baixo), algumas mulheres (umas na posição correta, outras não, uma delas nas mãos de um manifestante) -, a manifestação de outra política performada pela juventude nua, irreverente, mascarada (cuja visualidade remete aos controversos black blocs), ${ }^{24}$ que ocupa aquele recinto para lhe dar um novo uso. Muitas câmeras capturam o momento, o que manifesta outra partilha do sensível (RANCIÈRE, 2009) operada pelos manifestantes: deixarem de ser objeto cuja imagem é capturada pela mídia corporativa para serem produtores de suas próprias narrativas, em confluência com a de diversos outros usuários nas redes digitais. $O$ desejo de poder discutir conjunta e ativamente os rumos da vida pública foi vivenciado em 2013 nas ocupações das câmaras de vereadores ou, ainda, na plenária citada anteriormente, fazendo desses momentos marcos que tiveram repercussões nos anos seguintes, como, por exemplo, nas ocupações de escolas por estudantes em São Paulo ou no movimento nacional do Ocupa MINC, ambos em 2016.

Já a fotografia do gari, feita em um ângulo contraplongé que realça a postura imponente de um homem negro, que na distribuição cotidiana dos corpos na cidade é condenado à invisibilidade e à subalternização, funciona como uma "situação anormal de comunicação" que promove uma polêmica cena. Em cima das latas de lixo, seu instrumento de trabalho, o gari é a parte e o todo, que aparece na imagem no segundo plano, nos manifestantes, em sua maioria homens, que se concentram em frente a um imponente prédio histórico. Assim como o homem à frente, muitos dos garis vestem o uniforme da empresa de limpeza urbana Comlurb, em que se lê Prefeitura do Rio de Janeiro. A foto carrega algo de sonoro, pois há pessoas que parecem gritar, com braços erguidos, salvando a postura do homem, enquanto outros batem com pedaços de madeira as latas de lixo. Judith Butler (in DIDI-HUBERMAN, 2017, p. 26) afirma que "em geral, os levantes repousam numa metáfora estruturante: a imagem de alguém que se levanta, alguém para quem se levantar representa uma forma de libertação, alguém com capacidade

\footnotetext{
${ }^{24}$ O Black Bloc, que pode ser entendido tanto como movimento quanto como tática, ficou mundialmente conhecido em 1999 , com os confrontos ocorridos em Seattle, decorrentes da reunião da Organização Mundial do Comércio (OMC). Em 2013, popularizou-se no Brasil, estando na linha de frente das manifestações com máscaras (ou camisas) no rosto e escudos improvisados (alguns com inscrições anarquistas, pacifistas, entre outros signos e mensagens militantes), tal como podemos ver em uma fotografia que incluímos na prancha. Vale ressaltar que os black blocs foram criticados pela imprensa e por parte da opinião pública, que construiu um "inimigo abstrato", tal como afirma Ivana Bentes (2015, p.31): "A construção do medo, as figuras da desordem, dos 'vândalos', 'mascarados', depredadores do patrimônio público e privado, a figura do inimigo da ordem, encarnada pelos Black Blocs pós-manifestações de junho no Brasil, criam esse sujeito monstruoso ou anômalo, que é 'inimigo do poder"'.
} 
física de se libertar das amarras, das correntes, dos sinais de escravidão, da sujeição, do feudalismo". Tal fotografia condensa essa metáfora e ativa seu imaginário insurgente.

Corpos negros são a maioria neste protesto pelo aumento salarial e exigência de outros benefícios de trabalhadores tão estigmatizados socialmente. Ao insurgirem, mostram-se como coletivo forte; ao pararem suas atividade, fazem ver que a cidade sem eles seria um caos com odores insuportáveis. "Cidade Maravilhosa / Nós contribuímos para isso", "O prefeito quer fazer a Copa / Os garis querem fazer as compras", dizem as faixas ao fundo na foto; "R\$847,44 estamos sendo tratados como lixo", lemos em outra imagem. ${ }^{25} \mathrm{~A}$ tomada da palavra e a presença deste corpo coletivo em levante expõem a precarização do trabalho negro como marca de um passado colonial que se atualiza nas imagens, já que "essas são histórias 'persistentes', que não terminam com a mera troca de regimes; elas ficam encravadas nas práticas, costumes e crenças sociais, produzindo novas formas de racismo e de estratificação." (SCHWARTZ, 2019, p.32). O dissenso instaurado pelos garis em greve durante o maior evento da cidade, o carnaval carioca, é perceptível tanto nas imagens das ruas cheias de lixo como nos atos daqueles que afirmam não serem lixo. Se, no Brasil, "[...] o sistema escravocrata transformou-se num modelo tão enraizado que acabou se convertendo numa linguagem, com graves consequências" (SCHWARTZ, 2019, p.27), o rompimento com essa linguagem e, mais particularmente, com esse imaginário escravocrata, exige não somente o rebelar-se daqueles que são diretamente oprimidos, mas o reconhecimento dessas imagens revolucionárias como representativas da memória social/pública da democracia que desejamos. Afinal, o racismo continua sendo um dos maiores obstáculos para a realização do projeto democrático brasileiro. Nesta fotografia, concentra-se uma forte potência democratizante que se estende das jornadas 2013 às manifestações de 2014, na ampliação das reivindicações nas quais se manifestam cor e classe, fazendo esgarçar o racismo estrutural (ALMEIDA, 2018) de nossa sociedade e mais: a grandeza desses sujeitos e de seus levantes que atravessam séculos.

Em 2013, observamos como essas lutas foram se moldando, fazendo eclodir subjetivações políticas antirracistas. Para Rancière (1996, p. 47), a política é assunto de modos de subjetivação, entendendo esta pela “[...] produção, por uma série de atos, de uma instância e de uma capacidade de enunciação que não eram identificáveis num campo de experiência dado, cuja identificação portanto caminha a par com a reconfiguração do campo da experiência". Nesse sentido, vale inserir em nossa prancha a foto da faixa

${ }^{25}$ Disponível em: https://pt.globalvoices.org/2014/03/11/greve-de-garis-no-rio-de-janeiro-da-luta-a-vitoria/ 
assinada pela Rede de Comunidades e Movimentos contra a Violência, com a frase "A polícia que reprime na avenida é a mesma que mata na favela", ${ }^{26}$ que circulou exprimindo a perspectiva sobre a violência policial para uma parcela da população que convive com ela no cotidiano. Para esta, não há espanto ou revolta pontual, como ocorrera com a percepção da opinião pública diante da repressão dos protestos nas áreas centrais das cidades. O Estado é considerado assassino, racista e de exceção, é máquina de morte que assujeita política e existencialmente.

Voltar às imagens sobreviventes de 2013 e 2014 exige também encarar o fracasso do movimento, sobretudo quando nos deparamos com os rumos políticos antidemocráticos que se apresentam paulatinamente nos anos seguintes. Do arquivo do Atlas \#ProtestosBR, talvez a imagem mais sintomática desse fracasso seja a de Rafael Braga, homem negro preso em 2013 depois de uma abordagem policial e que até o atual momento se encontra em prisão domiciliar, concedida para tratar de sua tuberculose, contraída no cárcere. ${ }^{27}$ Rafael Braga é em si mesmo o símbolo de um estado racista, de uma democracia falha e de como as lutas populares acabam interferindo pouco na ordem policial institucional, pois, apesar de toda uma campanha contra sua condenação contraditória, é este "jovem, negro, pobre, catador de latinhas e morador da Vila Cruzeiro [...] o único condenado no contexto das manifestações de 2013 mesmo sem ter participado delas - por portar pinho sol e água sanitária". ${ }^{28}$ Sua foto é o retrato do preso político de 2013, condenado por um sistema cuja marca é a seletividade penal. Na luta por sua liberdade, 2013 persiste com o peso simbólico dos grilhões do passado.

\section{Considerações finais}

Este trabalho cartografou fotografias dos protestos de 2013 no Brasil, e alguns de seus prolongamentos em 2014, para em seguida concatená-las por meio da criação de uma montagem visual e de um relato textual. Perguntamo-nos como e por que essas fotos seriam entendidas como políticas (RANCIÈRE, 1996) ou, ainda, como tecnopolíticas (TORET, 2013), levando em conta que as práticas a elas associadas conectam multidões não somente nas redes digitais, mas nas redes sociotécnicas (LATOUR,

\footnotetext{
${ }^{26}$ A fotografia da faixa está presente no arquivo do Atlas \#ProtestosBR, mas não localizamos rastros de nenhum vínculo informativo nem a sua autoria. Podemos supor, contudo, pela mensagem escrita e em relação com a conjuntura de 2013 , que ela possa ter uma associação com os protestos contra a violenta ação policial na favela da Maré, em junho daquele ano, que resultou na morte de dez pessoas. Sobre isso, há um documento específico no site da Rede de Comunidades e Movimentos contra a Violência. Ver: https://redecontraviolencia.org/Documentos/903.html

27 Informação disponível na página de Facebook do movimento em prol da liberdade de Rafael Braga: https://www.facebook.com/liberdaderafaelbragavieira/

${ }^{28}$ Ver: https://www.liberdadepararafael.meurio.org.br
} 
2007) que se mobilizam para atribuir publicamente outros sentidos para vida comum, lutar pela conquista de direitos e expor assimetrias e injustiças sociais. A pesquisa nos permitiu recuperar rastros importantes dessas visualidades e de seus efeitos midiáticos em variados campos e linguagens - jornalismo corporativo, midiativismo, imagens amadoras, memes etc -, sendo que nos interessou particularmente entender as relações entre estas esferas discursivas tão diferentes entre si, mas que se comunicam como imagensredes. Por isso, optamos por escrever um relato contínuo de passagens e saltos, do particular ao todo, com o intuito de emular no texto a experiência de uma mirada que se aproxima e se distancia na prancha, percebendo-a como um mapa visual.

Buscamos entender as visibilidades que se manifestam nas interseções entre as práticas mediadas por tecnologias de imagem e comunicação digitais, e as cenas dos protestos que manifestaram um modelo comunicativo entre falas políticas múltiplas e longínquas umas das outras, mas que, ao se relacionarem, reconfiguraram em maior ou menor grau as maneiras de ser, fazer, ver e dizer (RANCIÈRE, 1996). Pela descrição das singularidades de cada fotografia, refletimos sobre o fazer político democrático dessa redistribuição de corpos, lugares e funções em protestos contemporâneos que, como parte constituinte destes, é performado em imagens para que estas sejam energia mobilizadora de afetos e de sentidos sobre o mundo comum. Investigamos nosso corpus de fotografias pela abordagem das tensões que elas próprias carregam e que fazem enlarguecer a gama de conflitos públicos. Assim, observamos que, em muitas dessas manifestações políticas, a imagem fotográfica lhe serve não somente como prova visual, mas como impulsionadora do prolongamento das mobilizações coletivas, sendo acontecimentos em si mesmas, em seus processos de concepção, produção e circulação. Há que se perguntar, todavia, quais riscos e limites dessas formas de exposição que eventualmente "transforma todo e qualquer protesto em espetáculo e todo espetáculo em mercadoria" (RANCIÈRE, 2012, p.35).

Antonio Negri (in DIDI-HUBERMAN, 2017, p.45) considera que diferentes elementos convergem no levante: a prática do acontecimento coletivo entre singularidades e diferenças; a tomada da palavra que 0 faz ser linguístico e performático, pois "[...] sem o dizer não há levante. Um manifesto, um escrito, uma inscrição, uma mensagem, um símbolo, uma bandeira; um simples aperto de mão para perguntar ou aprovar; ou ainda um punho fechado: são palavras"; e o exercício da força, "uma violência visando destruir a legitimidade de todas as instituições que pretendem exercer um comando inumano sobre nossa humanidade." Consideramos que essas três dimensões atravessam as imagens fotográficas aqui estudadas, 
que são uma forma de dizer, que fazem fazer e que fazem imaginar e desejar. Em suma, no levante contemporâneo, a prática existe para se tornar imagem, que carrega gestos, anseios e mesmo a violência genuína advinda da indignação. Logo, arriscamos dizer que não há protestos de 2013 sem as imagens de 2013, e que este imaginário prossegue de algum modo operante, mesmo que de forma latente, considerando que "a temporalidade do levante é descontinuada na zona de indeterminação radical, sem a qual não há revolução" (MONDZAIN in DIDI-HUBERMAN, 2017, p.53). Para Marie-José Mondzain (2012, p.101), a indeterminação é também atribuída às imagens que operam em uma "zona atópica": "As operações imaginantes surgem em uma zona sem lugar que coloca em relação aquilo que é sem relação". 29

As fotografias reunidas em nossa prancha, ao serem pesquisadas em ferramentas de busca por imagem, aparecem em narrativas as mais diversas, não somente em sites de notícias (o mais comum devido a seus sistemas de indexação), mas em blogs e páginas ativistas, além das redes sociais. São vetores de produção de subjetividade no momento da eclosão da revolta e de potencial rememoração que permite, mesmo após seu fracasso, levantar perguntas sobre "[...] qual versão de vontade popular tratamos, quem ela não inclui e por quê" (BUTLER in DIDI-HUBERMAN, 2017, p.35), o que é observável, por exemplo, na sobrevivência das imagens das lutas de 2013 nos anos seguintes, usadas pelo repertório ativista de alguns movimentos. Este aspecto coaduna-se com o comentário de Judith Butler (in DIDIHUBERMAN, 2017, p.31): “apesar de tudo, a história do levante fracassado pode se tornar uma referência e um precedente importante para outros levantes. [...] seu fracasso é o que dá ao levante uma chance de se tornar emblemático e incitar levantes futuros." Para a autora, diante de uma "história cumulativa dos levantes", "um levante sempre cita um outro e é animado por imagens e narrativas do anterior" (BUTLER in DIDI-HUBERMAN, 2017, p.31).

É notório que em 2013 foi construído todo um imaginário democrático cuja sobrevivência no presente contrasta com a emergência de posicionamentos neoconservadores e movimentos autoritários que atualizam nossa violenta história e esgarçam o recorrente desentendimento (RANCIÈRE, 1996) em torno da ideia de democracia, que no contexto brasileiro se mostra prática frágil. Os processos de rememoração que este estudo desejou ativar levam em conta a necessidade de abordar

\footnotetext{
${ }^{29}$ Tradução do texto: "Les opérations imageantes surgissent dans une zone sans lieu qui met en rapport ce qui est sans rapport. »
} 


\section{ALCEU}

ISSN: $2175-7402$

comparativamente esse repertório imagético - aqui apresentado em um breve recorte - em choque com aquele advindo das manifestações que emergiram desde 2015 até agora. Acreditamos que as visualidades e visibilidades políticas de 2013 servem como contrapontos dialéticos para a momento presente, que lançam perguntas complexas sobre o que é, ou pode ser, uma "manifestação política". Como afirma Judith Butler (in DIDI-HUBERMAN, 2017, p.24), "seria errado pensar que, no caso de um levante, este forçosamente se justifica ou que todo mundo está de acordo com seus objetivos políticos. Às vezes, é verdade, há levantes contra regimes democráticos." Ora, antecedentes não são causas, de modo que consideramos reducionista traçar apenas linhas de continuidade entre esses protestos, o que deve ser abordado no seguimento desta pesquisa, em um estudo da descontinuidade política desses movimentos que se faz ver nas agências das imagens.

Para concluir, citemos uma fotografia que incluímos na prancha, no intuito de reforçar essa sobrevivência do imaginário de 2013, que não somente circula nas imagens dos protestos passados, mas se faz presente em novos atos, ganhando outros corpos para se movimentar na memória pública brasileira. No protesto antifascista do dia 31 de maio de 2020, na Avenida Paulista, São Paulo, o fotógrafo Caio Castor captou o momento quando uma manifestante ergue o punho segurando na outra mão um papelão que cobre seu rosto, em que está escrito "PAREM DE NOS MATAR". ${ }^{30}$ Corpo negro no front, ao lado da barricada feita com um contêiner de lixo pichado com a frase "A luta continua", "ACAB" (acrônimo da expressão em inglês "all cops are bastards", slogan antipolícia que se popularizou com os protestos em decorrência do assassinato de George Floyd em 25 de maio de 2020), ${ }^{31}$ e abaixo deste, "2013", que no enquadramento de outra foto vemos complementado pelo verbo "vive". ${ }^{32}$

Os significantes da cena fazem relembrar os protestos de 2013: o gesto do punho erguido, a fumaça do fogo ateado na avenida, a barreira policial com escudos no segundo plano e o contraste com o contêiner que funciona como uma "barreira limítrofe" que "[...] separa a ordem policial da expressão política que promoveria um dissenso em seu interior" (MACIEL in BRASIL, 2017, p.23), diferentemente da ação de outros manifestantes que no mesmo dia saíram naquela avenida para apoiar a gestão do governo

\footnotetext{
30 Fotografia feita por Caio Castor para Pavio Jornalismo e Ponte Jornalismo, disponível em: https://twitter.com/CaioCastor/status/1267208020452413441

${ }^{31}$ Ver: https://www.vice.com/en_uk/article/akzv48/acab-all-cops-are-bastards-origin-story-protest

32 Fotografia disponível no site da benfeitoria em prol da agência Pavio Jornalismo, disponível em: https://benfeitoria.com/cobertura-da-pavio-sobre-coronavirus-e-direitos-humanos-gcp
} 
federal. Seus significados são múltiplos e oscilam entre aqueles que veem ali, mais uma vez, uma baderna violenta, ou quem considera estes movimentos convocados por torcidas organizadas de times de futebol declaradamente antifacistas um grito urgente de revolta em tempos de intensas controvérsias políticas. 2013 vive. Diz a frase escrita na barricada, dizem os corpos que junto a ela se dispõem a denunciar nas ruas as ameaças antidemocráticas e racistas mesmo durante uma pandemia, dizem as imagens que insistem em voltar como fantasmas que assombram o presente.

Jane Maciel

ORCID: https://orcid.org/0000-0002-6049-9793 Universidade Federal do Maranhão, Departamento de Comunicação Social, São Luís (MA), Brasil. Doutora em Comunicação e Cultura pela ECO/UFRJ E-mail: janmaciel@gmail.com

Recebido em: 31 de maio de 2020.

Aprovado em: 29 de junho de 2020.

\section{Referências:}

ALMEIDA, Silvio Luis de. O que é racismo estrutural? Belo Horizonte: Letramento, 2018.

BENTES, Ivana. Mídia-Multidão: estéticas da comunicação e biopolíticas. Rio de Janeiro: Mauad X, 2015.

DIDI-HUBERMAN, Georges. (org.). Levantes. São Paulo: Edições Sesc São Paulo, 2017.

. A imagem sobrevivente: história da arte e tempo dos fantasmas segundo Aby Warburg. Rio de Janeiro: Contraponto, 2013a.

. Atlas ou a gaia ciência inquieta. Lisboa: KKYM, 2013b.

DUBOIS, Philippe. O Ato Fotográfico e outros ensaios. Campinas: Papirus, 1993.

HALL, Stuart. Cultura e Representação. Rio de Janeiro: Ed. PUC-Rio: Apicuri, 2016. 
LATOUR, Bruno. Changer de société, refaire de la sociologie. Paris: Éditions La Découverte, 2007.

LIBÉRIO, Carolina. Eu que não quero ter rosto. Rio de Janeiro. Tese (Doutorado em Comunicação e Cultura). Escola de Comunicação, UFRJ, 2017.

MACIEL, Jane. Barreira Limítrofe: a que se opor nas/com imagens?. In: BRASIL, Ramusyo (org.). História, Política e Imagem Dialética. São Luís: EDIFMA, 2017.

MARICATO, Ermínia et al. Cidades Rebeldes: Passe livre e as manifestações que tomaram as ruas do Brasil. São Paulo: Boitempo, Carta Maior, 2013.

MONDZAIN, Marie-José. Les images zonards ou la liberté clandestine. In : CAVALCANTI, Ana Maria et al (org). ANAIS DO XXXII COLÓQUIO CBHA - Direções e Sentidos da História da Arte. Universidade de Brasília, 2012.

RANCIÈRE, Jacques. O ódio à democracia. São Paulo: Boitempo, 2014.

. O espectador emancipado. São Paulo: Editora WMF Martins Fontes, 2012.

A partilha do sensível: estética e política. São Paulo: EXO Experimental org.; Ed. 34, 2009.

. O Desentendimento: Política e Filosofia. São Paulo: Ed. 34, 1996.

SCHWARTZ, Lilia Moritz. Sobre o autoritarismo brasileiro. São Paulo: Companhia das Letras, 2019.

TORET, Javier. Tecnopolítica: la potencia de las multitudes conectadas. El sistema-red 15M como nuevo paradigma de la política distribuida. Informe de investigatión, 2013. Disponível em: <https://datanalysis15m.files.wordpress.com/2013/06/tecnopolitica-15m-resumen.pdf>. Acesso em: 11 mar. 2020.

\section{Resumo}

Os protestos de 2013 no Brasil marcaram a reflexão sobre como diversas tecnologias de comunicação participam das ações coletivas, entre elas, as fotografias, que tiveram um papel preponderante nesses movimentos. Neste artigo, buscamos problematizar o que seriam imagens/fotografias políticas nesta conjuntura brasileira e suas relações com o conceito de democracia. Por meio de uma metodologia exploratória de pesquisa, inventário, descrição e montagem de fotos, discutimos em um relato entre-imagens algumas das agências das fotografias entendidas não somente como prova visual ou registro mnemônico, mas como acontecimentos imagéticos que têm a potência de impulsionar a produção de comum. Usamos como base o arquivo do projeto Atlas \#ProtestosBR, visando abordar a constituição comunicacional das narrativas 
imagéticas desses levantes, e ainda, ativar essa trama de fotos compreendidas como atores-redes cujas rememorações e sobrevivências são tarefas políticas importantes contra o esquecimento e o entendimento reducionista desses movimentos e de seus desdobramentos.

Palavras-chave: Fotografia. Política. Democracia.

\section{Abstract}

The 2013 protests in Brazil brought upon a reflection as to how communicational technologies take part in collective actions, among those, photographs seem to have taken a preponderant role. In this article, we aim to problematize what a political image/photograph can be in the present Brazilian conjuncture and their relations to the concept of democracy. Through a methodology based on exploratory research, inventory, description and assemblage, we discuss in an in-between images account some of the agencies of photographs, taken not only as visual proof or mnemonic record, but as imaginal happenings with the potency to propel the production of a common. We used the files from the project Atlas \#ProtestosBR as a basis for our research, in an attempt to approach the communicational constitution of the imaginal narratives surrounding these protests, and also as a way to activate this weft of photographs as actors-networks whose remembrance and survival is an important political task against the forgetfulness and a reductionist understanding of these past events and their unfolding over the last years.

Keywords: Photography; Politics; Democracy.

\section{Resumen}

Las protestas de 2013 en Brasil marcaron la reflexión sobre cómo varias tecnologías de comunicación participan de las acciones colectivas, entre ellas, las fotografías, que desempeñaron un papel importante en estos movimientos. En este artículo, buscamos problematizar lo que serían imágenes/fotografías políticas en este contexto brasileño y sus relaciones con el concepto de democracia. A través de una metodología exploratoria de investigación, inventario, descripción y montaje fotográfico, discutimos en un relato entre-imágenes algunas de las agencias de las fotografías aquí entendidas no solo como prueba visual o registro mnemónico, sino como acontecimientos imagéticos que tienen el poder de conducir la producción del común. Usamos 
como base el archivo del proyecto Atlas \#ProtestosBR, con el objetivo de abordar la constitución comunicacional de las narrativas de imágenes de estas insurrecciones, y también para activar esta red de fotos entendidas como actores-redes cuyos recuerdos y supervivencias son tareas políticas importantes contra el olvido y la comprensión reduccionista de estos movimientos y sus consecuencias.

Palabras clave: Fotografía. Política. Democracia.

Este artigo é publicado em acesso aberto (Open Access) sob a licença Creative Commons Attribution Non-Commercial (CC-BY-NC 4.0), que permite que outros remixem, adaptem e criem a partir do seu trabalho para fins não comerciais, e embora os novos trabalhos tenham de lhe atribuir o devido crédito e não possam ser usados para fins comerciais, os usuários não têm de licenciar esses trabalhos derivados sob os mesmos termos. 